\title{
A multi-criteria analysis of options for energy recovery from municipal solid waste in India and the UK
}

\author{
H. Y. Yap and J. D. Nixon*
}

Faculty of Science, Engineering and Computing, Kingston University, Roehampton Vale campus, London, SW15 3DW, UK

*corresponding author, E-mail: j.nixon@kingston.ac.uk; Tel: 02084174727

\begin{abstract}
Energy recovery from municipal solid waste plays a key role in sustainable waste management and energy security. However, there are numerous technologies that vary in suitability for different economic and social climates. This study sets out to develop and apply a multi-criteria decision making methodology that can be used to evaluate the trade-offs between the benefits, opportunities, costs and risks of alternative energy from waste technologies in both developed and developing countries. The technologies considered are mass burn incineration, refuse derived fuel incineration, gasification, anaerobic digestion and landfill gas recovery. By incorporating qualitative and quantitative assessments, a preference ranking of the alternative technologies is produced. The effect of variations in decision criteria weightings are analysed in a sensitivity analysis. The methodology is applied principally to compare and assess energy recovery from waste options in the UK and India. These two countries have been selected as they could both benefit from further development of their waste-to-energy strategies, but have different technical and socio-economic challenges to consider. It is concluded that gasification is the preferred technology for the UK, whereas anaerobic digestion is the preferred technology for India. We believe that the presented methodology will be of particular value for waste-to-energy decision-makers in both developed and developing countries.
\end{abstract}

Keywords: Waste-to-Energy (WtE); Multi-Criteria Decision Making (MCDM); Analytical Hierarchy Process (AHP); Benefits Opportunities Costs and Risks (BOCR); energy policy. 


\section{Introduction}

Energy recovery from waste or waste-to-energy (WtE) has become an attractive option for many countries as an effective waste management solution. WtE technologies can provide valuable energy, reduce the burden on the land required for landfill disposal and mitigate greenhouse gas emissions. As a result - and despite a recent economic crisis - the global market for $\mathrm{WtE}$ technologies has experienced substantial growth (World Energy Council, 2013a) and there are now over 1200 operating plants across 40 countries (Ghosh, 2014).

WtE technologies include any waste treatment system that creates energy in the form of electricity, heat or transport fuels from a waste feedstock. These technologies can process many types of waste (e.g. sewage, medical waste, industrial gases etc.), but the most common application is for processing municipal solid waste (MSW). In 2012, the annual global generation of MSW was estimated to be 1.3 billion tonnes, and it is expected to rise to 2.2 billion tonnes by 2025 (Hoornweg and Bhada-Tata, 2012).

Whilst there is a great potential for generating energy from waste, there are many challenges ahead for the WtE industry and many of the barriers for further development are unique to each country. Policy uncertainties, economic challenges and competition with non-renewable energy sources are some of the key concerns facing the WtE industry (IEA, 2013). The varying composition of waste that changes radically from low-income to high-income countries is also a major issue for deciding on the suitability of different technology types. This is particularly relevant to countries such as India and UK, as they have been identified as countries that require improvements to their waste management strategies (Jamasb and Tooraj 2010 and Unnikrishnan and Singh, 2010), but have very different MSW characteristics and socio-economic challenges to overcome.

The Asia-Pacific region has been predicted to be the fastest growing market for WtE with major expansions expected in countries such as India (World Energy Council, 2013a). Urban MSW 
generation in India is approximately 40 million tonnes per annum (Hoornweg and Bhada-Tata, 2012) and is expected to rise at an annual rate of $1.33 \%$ (EAI, 2013). Most of the collected MSW in India is disposed of through unsanitary landfills or uncontrolled dumping in city outskirts (Singh, et al., 2011). The Indian Ministry of New and Renewable Energy predicted a $1500 \mathrm{MW}$ power generation potential from MSW, but only $2 \%$ of the $\mathrm{WtE}$ potential has been realised (EAI, 2013). Previous attempts on recovering materials and energy from MSW in India have encountered numerous setbacks. One reason which has been attributed to the unsuccessful deployment of WtE in India is that local conditions have not been taken into account (Aswani, 2012). MSW in India is typically high in organic content at round 50\% (EAI, 2013). In comparison, MSW in the UK has an average composition of approximately $50 \%$ recyclables, $34 \%$ biodegradable waste (food, garden and other organic wastes) and 16\% other miscellaneous wastes (Defra, 2009) (see Figure 1a-b).

The UK has predominantly relied on landfills for managing waste in the past. However, this has changed in recent years with waste being diverted from landfills due to stringent legislations and policies such as the EU Landfill Directive (1999/31/EC) (Defra, 2014a). The percentage of waste treated in England through WtE systems is forecasted to rise to $20 \%$ by 2020 (IEA Bioenergy, 2012). Another driver for $\mathrm{WtE}$ facilities in the $\mathrm{UK}$ is that they can contribute towards a renewable energy target of having $15 \%$ of the total UK energy generation portfolio being provided by renewable sources. In the past few years, a combination of different market mechanisms and incentives has been introduced by the UK government to promote more $\mathrm{WtE}$ activities. However, the UK still faces some major obstacles to the growth of WtE such as public opposition, policy inconsistencies, planning restrictions and financing issues.

Strategic decision making for WtE technology selection is highly complex, especially given the growing number of emerging technological alternatives. Operations research techniques such as Multi-Criteria Decision Making (MCDM) tools are established methods to aid decision makers compare and evaluate technologies. These tools have been widely used throughout the energy 
industry (Zhou et al., 2006 and Løken, 2007) and are growing in popularity within the field of waste management (Aravossis et al., 2001, Hsu et al, 2008 and De Feo and De Gisi, 2010). Studies specific to the application of such tools in MSW management mainly focus on site and treatment strategy selection (Soltani et al, 2015). However, many inappropriate technology selection choices are still being made by key $\mathrm{WtE}$ decision makers and research has identified the need for a wider uptake of MCDM methods to address this problem (Nixon et al., 2013a). Whilst the environmental impacts of different WtE technologies have been compared using life cycle assessment tools (Arena et al., 2015 and Evangelisti et al., 2015), there is also a requirement for an MCDM tool that can enable all the trade-offs between the advantages and disadvantages of different technology types operating in varying locations to be assessed. Addressing this gap will facilitate and enhance the global deployment of WtE technologies.

This paper aims to examine and compare WtE technologies used for energy recovery from MSW in developed and developing countries. A specific objective of the study is to outline and demonstrate an MCDM model for evaluating WtE technologies based on countries' unique socio-economic and technological environments. To achieve this, decision making criteria will be determined for the assessment of WtE technologies, and the model will be applied principally to case studies for India and the UK. An outcome from the study will be a methodological approach that can be applied to other countries by researchers and decision makers.

The next section outlines the methodology developed to achieve the aim and objectives of this study. Section 3 explains the decision making model used for analysing WtE technologies. Section 4 follows on with a detailed review of WtE technology alternatives in India and the UK. The output of the review is fed into the model as described in Section 5 and a sensitivity analysis is performed to examine the impact of different opinions on the results of the evaluation. Finally, Section 6 discusses the findings and a conclusion is provided in Section 7. 


\section{Methodology}

The decision making model is initially developed by reviewing MCDM methods and their applications for waste management and energy planning. This enables the most widely used MCDM methods to be identified and determines areas within existing models requiring improvement for the desired application. A review of WtE technologies is performed to gather data and determine suitable evaluation criteria for both India and the UK. The criteria considered encompass a range of financial, technological, environmental and economic factors, and are comparable to those used in similar technology evaluation studies (Hokkanen and Salminen, 1997; Aravossis, et al., 2001; Nixon, et al., 2013b; Stein, 2013; and Ahmad and Tahar, 2014).

To develop credible decision preferences (i.e. provide importance weightings for the selected evaluation criteria), six academic experts - three from India and three from the UK - who specialise in WtE have been engaged and their opinions gathered using surveys. The data collected from the technical review and experts is then fed into an MCDM model to evaluate and compare WtE technologies for India and the UK. The MCDM analysis is performed in SuperDecisions ${ }^{\circledR}$ which is a well-established software package for carrying out MCDM studies based on mathematical decision making theories, and it has been applied by a number of researchers in other studies (Atmaca and Basar, 2012 and Banar, et al., 2007). The overall outcome from the MCDM model is a preference ranking for each technological alternative. To take into account the potential variations in experts' opinions and gathered data, a sensitivity analysis is conducted. Based on the MCDM results, recommendations for the development of $\mathrm{WtE}$ in India and the $\mathrm{UK}$ are made.

\section{The AHP-BOCR Decision Making Model}

The most well-known MCDM methods include Multiple Attribute Utility Theory (Keeney and Raiffa, 1993), Analytical Hierarchy Process (Saaty, 1980), Analytical Network Process (Saaty, 2001), Preference Ranking Organization Method for Enrichment Evaluation (PROMETHEE) (J.P. 
Brans, 1986), Elimination et Choice Translating Reality (ELECTRE) (Roy, 1991) and Technique for Order Preference by Similarity to Ideal Solution (TOPSIS) (Hwang and Yoon, 1981). A number of authors have reviewed these methods for the application of aiding waste management and energy planning decisions. Soltani, et al. (2015) reviewed the use of MCDM in the area of MSW management and Løken (2007) highlighted the advantages and disadvantages of each MCDM method for evaluating energy planning problems. Other reviews of MCDM methods applied in sustainable energy decision making have been discussed by Pohekar and Ramachandran (2003), Wang, et al. (2009) and Scott et al. (2012). These authors concluded that there is great potential for MCDM methods in field of MSW management and energy planning.

Whilst one MCDM method is not necessarily better than the other (Løken, 2007), the Analytical Hierarchy Process (AHP) has proved to be the most widely applied decision making method in terms of number of journal publications (Aragonés-Beltrán, et al., 2014). The AHP, first introduced by Saaty (1977), is very popular for evaluating technology alternatives in both MSW management and energy planning problems. Specifically, in the MSW management field, a review of 68 decision making studies found that AHP, and its associated family of methods, accounted for $65 \%$ of the published papers (Soltani, et al, 2015).

Additional strategic frameworks can be integrated in AHP to improve the decision making rationale; however, research in this area has been limited for MSW management (ibid.). To deal with the bipolarity of decision attributes more comprehensively, Benefits, Opportunities, Costs and Risks (BOCR) merits can be introduced into the AHP method. Solving a problem by BOCR analysis considers both positive attributes (Benefits and Opportunities) and negative attributes (Costs and Risks) to determine a preference of alternatives in relation to a specific goal. BOCR is in certain ways similar to a Strengths, Weakness, Opportunity and Threats (SWOT) analysis, as it is a framework which looks into the positive and negative aspects of a problem through internal and external factors. However, there are differences in their applications: SWOT is usually used to 
analyse a business problem at a single instance, but repeatedly over a period of time; while BOCR can be applied to analyse both short and long term influencing factors surrounding a problem. There is also a tendency for a SWOT analysis to be used qualitatively and not quantitatively (Zoffer, et al., 2008). Thus, the integration of BOCR into AHP allows for a more comprehensive way to achieve meaningful preference scores (Saaty, 2004), and it is well suited for the purpose of comparing and assessing energy technologies.

Recent literature using the AHP-BOCR method for energy planning include a strategic analysis of wind farm projects in China (Lee, et al., 2009), an analysis for the selection of solar-wind hybrid power generation projects in China (Chen, et al., 2010), and the evaluation of sustainable renewable energy sources for North Korea based on the views of different stakeholders (Yi, et al., 2011). In terms of waste management, the AHP-BOCR method has also been applied to determine a suitable landfill site in Turkey (Banar, et al., 2007). The combination of the BOCR framework with AHP is a more intuitive decision making method, particularly for energy technology projects where it is useful to investigate the trade-off between BO and CR. Thus, this model will be used to evaluate the feasibility of WtE projects in India and the UK.

The general idea of the AHP method is to decompose a complex problem into hierarchical levels, and then determine preference rankings of the decision alternatives through applying weightings based on the judgement of selected respondents. The alternative with the highest weighing is then generally the most preferred outcome. The AHP-BOCR model is developed based on a standard AHP model. The research problem is decomposed into hierarchical levels with the research goal being placed at the top. As illustrated in Figure 2, the first level in the hierarchy consists of the four merit clusters: $\mathrm{B}, \mathrm{O}, \mathrm{C}$ and $\mathrm{R}$, the second level contains networks of the BOCR sub-criteria and the final level consists of all alternatives considered. A technology review is required to provide data for each of the hierarchical levels in order for the decision making technique to be carried out. 


\section{Waste to Energy Technology Review in India and UK context}

An overview of WtE systems and their energy outputs is provided in Figure 3. The thermochemical conversions processes reviewed in the context of India and the UK include incineration with raw MSW and refuse-derived fuel (RDF), pyrolysis and gasification. The biochemical conversion technologies considered are anaerobic digestion (AD) and landfill with gas recovery.

\subsection{Incineration}

Incineration, also known as mass burn, is the most commonly used technology for WtE and has the capability of achieving up to $90 \%$ volume reduction of MSW (Singh, et al., 2011). The Manual on MSW Management (CPHEEO, 2000) states that a 300 tonnes per day (tpd) incineration plant requires approximately 0.8 hectares of land. Overall conversion efficiencies are typically in the region of $18-26 \%$ (Lombardi, 2015). Incineration of waste with high moisture content can lead to energy losses through drying. Therefore, this type of technology has not performed well in India due to MSW being high in biodegradable content ( $\sim 50 \%)$, high in moisture (40-60\%) and low in calorific value $(800-1100 \mathrm{kcal} / \mathrm{kg}$ ) (Unnikrishnan and Singh, 2010). With these characteristics, it is difficult for combustion to be self-sustaining without the support of auxiliary fuels. This was one of the major problems that led to the closure of India's first large scale incinerator built in 1985 in Timarpur (Asnani, 2006).

Emissions from incinerators contain many pollutants $\left(\mathrm{CO}_{2}, \mathrm{SO}_{\mathrm{x}}\right.$, and $\mathrm{NO}_{\mathrm{x}}$, etc. $)$, but they can be significantly reduced through the use of appropriate pollutant control systems. Murphy and Mckeogh (2004) reported that MSW incineration generating only electricity can produce approximately $220 \mathrm{~g} \mathrm{CO}_{2} / \mathrm{kWh}_{\mathrm{e}}$ based on a net conversion efficiency of $15.3 \%$. However, they do note that it is difficult to establish precise values due to the varying composition of MSW. Emission regulations are not as stringent in India as compared to those for the UK. For example, incineration plants in the UK have to comply under the strict emission limits through the Industrial Emissions 
Directive (IED) 2010/75/EU. The Timarpur-Okhla waste incineration plant in India which started operations in 2012 was reported to exceed pollution levels by more than 25 times above permitted levels (Kelkar, 2013). Besides air emissions, moderate water pollution in thermochemical WtE systems occurs from water being used in scrubbing.

Capital costs in the UK for plants ranging from 100-200 ktpa have been estimated to be around 620700 \$/tpa (400-450 £/tpa) (Greater London Authority, 2008). Capital costs in Europe have been estimated to reach as high as 500 Euros/tpa for plant capacities in the region of $500 \mathrm{ktpa}$; however, they are often a lot less (Massarutto, 2015). Gross operations and maintenance (O\&M) costs for incineration plants are typically around $10 \%$ of the capital costs (Greater London Authority, 2008). The capital cost of incineration plants in India has been reported to be around $22-42 \%$ of the price of EU and US WtE facilities (World Energy Council 2013b). Operational costs for incinerators in India are estimated to be around $85 \$$ /tonne (Chakraborty, et al., 2013). However, in India, there is a lack of expertise and experienced contractors to design and build thermochemical WtE plants (Dey, et al., 2014). Thus, skilled resources have to be imported from other countries and this drives up initial investment costs.

One of the main sources of revenue for a WtE facility in the UK are gate fees which are in the range of 100-140 \$/tonne (65 - $90 £ /$ tonne) of MSW (WRAP, 2014). In India, there is typically no gate fee system for any type of $\mathrm{WtE}$ plant. This means that the only source of revenue is through the sale of electricity and by-products. Profitability of incineration plants can also be improved through the recovery of valuable metals. There is also potential for bottom ash to be sold as an aggregate for construction (Defra, 2013a). A number of other government support mechanisms have been introduced to encourage the development of WtE (WRAP, 2012). These include the Renewable Obligation Certificate (ROC), Renewable Heat Incentives (RHI) and feed-in-tariffs (FIT). Incineration WtE projects can currently earn $1 \mathrm{ROC} / \mathrm{MWh}$ (only if it is a qualifying combined heat and power system); RHIs are available at $0.04 \$ / \mathrm{kWh}(2.7 \mathrm{p} / \mathrm{kWh})$ for the organic fraction of waste, 
whereas FITs are available at $0.17-0.19 \$ / \mathrm{kWh}(11-12.5 \mathrm{p} / \mathrm{kWh})$ but only for micro CHP systems (2kWe or less). India's Ministry of New and Renewable Energy has declared accelerated financial assistance for WtE projects under the National Program on Energy Recovery (Zhu, et al., 2009), but no support is currently available for incineration unless RDF is utilised.

\subsection{RDF incineration}

Municipal waste can be pre-treated before combustion to produce RDF. RDF consists of the dry combustible fraction of MSW and is generally in the form of fluff or pellets. Whilst RDF is produced to have a high energy content, its composition and calorific value is dependent on the source of waste and separation process. The additional benefits of RDF as the feedstock for incineration include more homogenous content, improved reliability and cleaner emissions. RDF pellets are also relatively easy to store and transport. Due to the high combustible content and reduced water content in RDF, steam cycle efficiencies can be potentially improved in comparison to conventional incineration (Fitzgerald, 2014). However, increased parasitic loads for RDF processing reduce net conversion efficiencies. Waste volume reduction rates for RDF are similar to mass burn incineration, although this is only for the separated fraction of MSW.

The market for local RDF use in the UK is still considered immature. However, 1.58 megatonnes of RDF was exported from the UK in 2013 (Defra, 2014b). The RDF experience in India includes 5 RDF plants installed near Hyderabad, Vijayawada, Jaipur, Chandigarh and Rajkot. The RDF plants in Hyderabad, Vijayawada and Chandigarh have had severe problems which have resulted in plant closures and public opposition to RDF plants. Nevertheless, attempts at installing RDF-based plants in India are still on-going (Kalyani and Pandey, 2014).

Although the costs for the RDF processing equipment can be high, furnace sizes are typically reduced and conversion efficiencies can be improved (Rand, et.al, 2000). Therefore, the capital costs of an RDF incineration plant in the UK are assumed to be comparable to a mass burn 
incineration plant. In India, the capital cost of a proposed $10 \mathrm{MW}$ RDF facility in Ghazipur, with a capacity of $429 \mathrm{ktpa}$ of MSW, was expected to cost approximately $135 \$ /$ tpa of processed RDF (UNFCCC, 2006). There is also scope for RDF to be co-fired in existing coal-fired power plants. This would reduce initial investment costs as the main expense would be for system modifications and waste pre-processing equipment. As RDF generation can involve dehydrating, shredding and palletisation - which might take place at a separate site - operational costs are increased. In India, the National Program of Energy Recovery offers an incentive of 230,000 \$/MW (15 million Rs./MW) of power generated from MSW involving RDF. In the UK, financial support for RDF is similar to mass burn incineration. In addition to financial incentives, RDF incineration plants need to rely on profits from material recovery to be competitive with mass burn incineration (Fitzgerald, 2013).

\subsection{Gasification}

Gasification is an advanced thermochemical treatment process that involves the partial oxidation of a substance. Whilst gasification is a well-established technology, there are a limited number of commercially proven plants processing MSW (Tanigaki, 2015). Typically, MSW does require some form of pre-treatment before it can be gasified; however, this does depend on the gasification reactor design and configuration (Tanigaki, 2012). The main product from gasification is a syngas which can be combusted to produce energy. Syngas can also be used to produce chemical feedstocks and liquids fuels. However, the composition of raw syngas can be variable and it is difficult and expensive to condition and clean (Richardson et al., 2012). At around 18-22\%, overall waste to electricity conversion efficiencies for gasification used with a conventional steam cycle are comparable to incineration. Nevertheless, conversion efficiencies can be increased to around 26$28 \%$ through the use of a gas engine or up to $30 \%$ with a gas turbine (Greater London Authority, 2008 and Arena, 2012). As gasification plants are generally more complex than incinerators, they do tend to be more costly. 
In the UK, capital costs for gasification WtE plants have been reported to range from 620-850 \$/tpa (450-550 £/tpa) for capacities of 100-200 ktpa (Greater London Authority, 2008 and Defra, 2013b). Whilst there are many gasification systems in India, there are no established gasification plants processing MSW. A wide range of capital costs have been reported for gasification plants in India (NRI, 2012) and, for the purposes of this study, the cost is assumed to range from 170-300 \$/tpa. The operational costs for gasification systems in India and the UK have been reported to be $65-112$ \$/tonne (Nixon, et al., 2013b) and 70-90 \$/tonne (45-60£/t) (Greater London Authority, 2008) respectively. In India, 610,000 \$/MW (39 million Rs./MW) of financial support is available for gasification systems. Waste gasification technologies in the UK are eligible to earn 2 ROCs/MWh and $0.1 \$ / \mathrm{kWh}$ in RHIs.

Gasification plants have a number of other advantages in comparison to incineration. They are capable of reducing the volume of waste by up to $95 \%$ (Wong and Tam, 2014) and flue gas clean-up is generally less intensive. $\mathrm{CO}_{2}$ emissions have also been reported to be lower than an incinerator at around $114 \mathrm{~g} \mathrm{CO}_{2} / \mathrm{kWh}_{\mathrm{e}}$ (Murphy and Mckeogh, 2004). This is due to the assumption of a higher net conversion efficiency of $27.2 \%$, and greenhouse gas emission per kilowatt hours will be of the same order if the entire thermal product is utilised. Modern gasification systems have an enclosed nature of operation and this decreases the chance of groundwater pollution, and water pollution is most likely to be associated with transport and waste collection (Defra, 2013b). The size and land requirement for a gasification plant is comparable to a conventional $\mathrm{WtE}$ incineration plant. Nevertheless, the reliability of gasification plants can still be a concern and the syngas cleaning process remains the major challenge for gasification-based WtE plants. As a result, it is difficult for gasification plants to gain financial support and investment for commercialisation. 


\subsection{Anaerobic Digestion}

$\mathrm{AD}$ involves the biodegradation of organic matter by anaerobic microorganisms in the absence of oxygen to produce biogas. As $\mathrm{AD}$ can only be utilised for the organic fraction of MSW (OFMSW), there must be good source segregation and collection practices. Overall electrical energy conversion efficiencies have been reported to be in the range of $10-12 \%$ based on gas engines (Greater London Authority, 2008), and a 300 tpd $\mathrm{AD}$ plant requires approximately 2 hectares of land (CPHEEO, 2000). In Europe, $56 \%$ of MSW AD plants produce heat and electricity, $16 \%$ inject purified biogas into the gas grid and 28\% trade biogas for use as a transport fuel (Iacovidou, et al, 2013). In the $\mathrm{UK}, \mathrm{AD}$ is well-established for domestic sewage and organic waste treatment; however, it is only just maturing for energy generation from municipal waste (Mallapaty, 2011).

In India, there is limited experience in $\mathrm{AD}$ treatment of solid organic waste except for animal manure and sewage sludge (Unnikrishnan and Singh, 2010). As MSW in India is high in moisture and organic content, it is well-suited for anaerobic digestion (Singh, et al., 2011). However, large scale AD plants in India face difficulties with obtaining separated OFMSW and this issue contributed towards the failure of a $6 \mathrm{MW}$ electricity generation plant in Lucknow. Nevertheless, success has been proven in smaller scale AD plants using feedstocks from restaurants, hotels and food markets (Kalyani and Pandey, 2014).

The organic fraction of MSW in AD plants is reduced by approximately $70 \%$ (Hartmann and Ahring, 2005); therefore, with the estimated average organic fraction of MSW in India and UK being $50 \%$, and $34 \%$ (see Figure 1), the total MSW volume is reduced respectively by $35 \%$ and $24 \%$. With small scale AD plants, the variability of the MSW feedstock in India does not typically affect the energy content of biogas produced through $\mathrm{AD}$ due to on-site separation of non-digestible materials and the advantage of long retention times (Planning Commission, 2014). In terms of environmental impact, $\mathrm{AD}$ has a low global warming potential and has been reported to provide net positive environmental gains (CPHEEO, 2000). However, as proper waste management regulations 
with regards to health and safety are not in place, there are potential health risks in India due to exposure to pathogenic content of MSW during transport. There can also be risks of asphyxiation and explosions in $\mathrm{AD}$ systems due to the build-up of methane.

Investment costs for $\mathrm{AD}$ are considerably lower than thermochemical $\mathrm{WtE}$ systems. One $\mathrm{AD}$ plant in Pune, India reported to the authors that the capital cost for their 10 tonne per day AD plant was $50 \$ /$ tpa. O\&M cost is estimated to be $1-6 \%$ of the capital costs or around 5-30 \$/tonne (IRENA, 2012). The capital cost for $\mathrm{AD}$ plants in the UK is around 310-460 \$/tpa (200-300 £/tpa) (Greater London Authority, 2008). Whilst, digestate is potentially a valuable AD by-product, there is some market uncertainty. As a result, in the UK some plants are giving it away to farmers for free and in India it is often spread over large city gardens. The Indian government provides up to 310,000 \$/MW (20 million Rs./MW) to support AD WtE plants. The UK government's AD Strategy and Action Plan (Defra, 2013c) outlines a roadmap to increasing energy generation from waste using $\mathrm{AD}$. This action plan's incentives for $\mathrm{AD}$ includes ROCs available at $2 \mathrm{ROCs} / \mathrm{MWh}$ generated, 0.1 $\$ / \mathrm{kWh}(6.8 \mathrm{p} / \mathrm{kWh})$ of RHIs for biogas combustion or biomethane injection projects, and FiTs for small scale $\mathrm{AD}$ electricity generation at $0.15-0.23 \$ / \mathrm{kWh}(9.9-14.7 \mathrm{p} / \mathrm{kWh})(\mathrm{ARUP}, 2015)$. AD facilities in the UK also gain revenue through gate fees which were reported in 2014 to be at an average of $60 \$ /$ tonne (40£/tonne) (WRAP, 2014).

\subsection{Landfill Gas Recovery}

Landfill gas (LFG) recovery sites are modern landfills with strict sanitary and environmental standards which treat and collect leachate, as well as capture landfill gas for energy generation. Landfills require large land areas and can take up to 36 hectares (CPHEEO, 2000). This may cause concern as landfill space has become scarce in certain countries. The UK is one of the global leaders in LFG recovery; by the end of 2013, there were over 435 plants forming a total installation capacity of over $1 \mathrm{GWe}(\mathrm{DECC}, 2014)$. With a range of $1-1.2 \mathrm{~kg} \mathrm{CO}_{2} / \mathrm{kWhe}$, greenhouse gas 
emissions from LFG recovery sites are higher than from other WtE technologies (Nixon, et al, 2013b). The EC Landfill Directive (99/31/EC) sets mandatory targets for the reduction of biodegradable MSW sent to landfill and the current imposed tax for standard waste deposited in UK landfill sites is 120 \$/tonne (HMRC, 2014).

In India, $90 \%$ of MSW in cities is directly disposed into landfill in an uncontrolled manner (Singh, et al., 2011). As of 2011, there were no known sanitary LFG recovery and energy production sites in India (Siddiqui and Khan, 2011). However, there is a good potential for collecting gas from large old landfill sites (Mazumdar, 2008). In addition to the typical environmental and social hazards of landfill sites, infectious waste content is a concern in India due to a lack of segregation and regulations (Sharholy, et al., 2008). Other barriers identified in using LFG as an energy source in India include technological complexities and financial limitations (Mazumdar, 2008).

The capital cost of developing a sanitary landfill with gas recovery is relatively low. In India, the capital cost for a $1.5 \mathrm{MW}$ landfill site has been estimated to be 3.3 million US Dollars (Kumar and Sharma, 2014). Given that an 800 tpd LFG plant in Thailand can generate $1 \mathrm{MW}_{\mathrm{e}}$ (Kumar and Kumar, 2014), it is assumed that the capital cost for plants in India would be in the region of 10 \$/tpa. In the UK, the capital costs for landfill gas recovery have been reported to range from 1.2-1.5 million $\$ / \mathrm{MW}_{\mathrm{e}}$ for sites generating less than $2 \mathrm{MW}_{\mathrm{e}}$. These figures are at least $50 \%$ less than the capital costs for an AD plant of comparable size (ARUP, 2011). Operations and maintenance costs have been considered to be in the region of $0.4-0.7 \%$ of the capital cost (Bove and Lunghi, 2006). In comparison with other $\mathrm{WtE}$ technology alternatives, LFG recovery gains the least governmental support from the UK and India. In the UK, closed landfill sites are eligible for $0.2 \mathrm{ROCs} / \mathrm{MWh}$ and landfill heat recovery sites are eligible for $0.1 \mathrm{ROCs} / \mathrm{MWh}$. Non-hazardous landfill sites in the UK are also eligible for gate fees which were reported to be at an average of $33 \$ /$ tonne ( $21 £ /$ tonne) (WRAP, 2014). In India, there are no known financial incentives for the development of sanitary LFG recovery sites. 


\subsection{Output of Technology Review}

The collected data was grouped and arranged into BOCR categories as outlined in Table 1 . The collected data is used to guide the authors' decisions for pair-wise comparisons through the AHP decision making process. The output of the technology review is summarised in Tables 2 and 3. Due to the paucity of information, pyrolysis has been excluded from the study.

\section{AHP-BOCR Analysis}

To obtain weightings for the criteria and sub-criteria levels of the hierarchy (see Figure 2), academic experts were requested to complete a survey to rank the importance of the BOCR groups and subcriteria through pair-wise comparisons using Saaty's recommended 1-9 weighting scale: where 1, 3, 5, 7 and 9 respectively indicates equal preference, moderate preference, strong preference, very strong preference and extreme preference, and 2, 4,6 and 8 are compromises for the preferences in between 1, 3, 5, 7 and 9 (Saaty, 1977). Average scores based on the survey responses were then used to complete the pair-wise comparisons, and SuperDecisions ${ }^{\circledR}$ was used to compute the priority weighting (see Figure 4). As the full mathematical process for completing AHP pair-wise comparisons and analyses is well described elsewhere (Saaty, 1980 and Saaty, 2001), it is omitted from this paper.

The preference of each $\mathrm{WtE}$ technological alternative for each criterion was then determined using the data collected from the literature review (Table 2 and Table 3). This was achieved through pairwise comparisons of the alternatives with respect to each sub-criteria in every BOCR group. The question considered in each comparison was: which of the two technologies compared has the greater positive factor (Benefit/ Opportunity) or greater negative factor (Cost/ Risk). To ensure consistency of judgements, the consistency ratio of the judgements is derived using Saaty's randomly generated indexes (Saaty, 1977). Through this process, each technological alternative is 
assigned with a priority score for each sub-criteria and a total rating for each Benefits, Opportunities, Costs and Risks cluster.

An overall preference ranking for each technological alternative can be determined in different ways in an AHP-BOCR analysis (Saaty, 2004). In this study, the final preference rankings of the technologies were calculated using the formula $b B+o O-c C-r R$, where $b, o, c$ and $r$ are the total ratings for each technology against each BOCR cluster (see Figure 5a-d), and $B, O, C, R$ are the overall preference weightings for the Benefits, Opportunities, Costs and Risks groups, as determined by the academic experts. As the formula subtracts the sum of the prioritized Costs and Risks (negative factors) from the sum of the prioritized Benefits and Opportunities (positive factors), the final rankings can turn out to be negative, which is a strong indication that an alternative is highly undesirable (Saaty and Sodenkamp, 2010).

\section{Results and Discussion}

Figure 5a-d shows the priority rankings within each BOCR group for all technology alternatives in the UK and India. AD has the highest ranking for both the Benefits and Opportunities Indian group with $26 \%$ and $40 \%$ respectively. Sanitary LFG is a close second in terms of Benefits for India, with only a $0.6 \%$ difference compared to the Benefits of $\mathrm{AD}$. Gasification is identified as having strong Opportunities in India with a ranking of $34 \%$. For the UK, incineration and gasification lead the Benefits group with $32 \%$. RDF incineration has good Benefits in the UK with a $25 \%$ preference ranking. In terms of Opportunities in the UK, gasification is ranked the highest with $43 \%$.

The results for the Costs group are similar for both India and the UK. Gasification is ranked as the most costly technology with $36 \%$ for India and $39 \%$ for the UK. With around $4 \%$, LFG is the least costly technology for India and the UK. For the Risks group, gasification is ranked highest for India with $36 \%$, whereas LFG is ranked as the highest risk technology in the UK with $46 \%$. The WtE 
technology with the least risk for both India and UK is RDF incineration, which has a ranking of $9 \%$ and $10 \%$ respectively.

When Benefits, Opportunities, Costs and Risks are synthesised by the $b B+o O-c C-r R$ formula to obtain an overall preference ranking, there is a clear difference between the preferred technologies in India and the UK. With an overall preference ranking of $53 \%$, $\mathrm{AD}$ is the most suitable $\mathrm{WtE}$ technology for India. In comparison, gasification is considered the most feasible technology for the UK with an overall preference ranking of $38 \%$. The second highest ranked technology in India is gasification with a preference ranking of $23 \%$. This is approximately half of AD's preference ranking and hence this demonstrates a clear preference towards $\mathrm{AD}$ in India. With an overall ranking of $15 \%$, RDF incineration is the third most preferred WtE technology in India. For the UK case study, $\mathrm{AD}$ is the second highest ranked technology with $19 \%$ and incineration is third with $5 \%$.

For the India case study, sanitary LFG recovery scored only 3\% making it the least preferred technology. LFG recovery and RDF incineration are found to be highly undesirable technologies for the UK with an overall preference ranking of $-30 \%$ and $-8 \%$ respectively. Overall preference rankings for all the MSW energy generation technologies in India and the UK are illustrated in Figures 6 and 7.

For a particular technology alternative to have a higher overall ranking, Benefits and Opportunities require high priority ratings, and Costs and Risks need to have lower priority ratings. The strong preference for $\mathrm{AD}$ in India is attributed to its technology compatibility with local MSW, superior market establishment and the fact that it achieved low priority scores for the Risk sub criteria within the decision framework. The favourable results for $\mathrm{AD}$ reflect the potential of small scale $\mathrm{AD}$ plants in India. Even though gasification has the highest priority ranking in the Costs and Risks groups, it turned out as the second most preferred technology alternative. This is due to Costs receiving a group importance weighting of only 0.08 . Therefore, the high initial investment cost for gasification 
does not negatively impact the overall preference rankings. In addition to this, gasification also fared well in the Opportunities group (34\%) due to more government funding opportunities in comparison with other technologies.

For the UK, the Benefits group obtained an importance weighting of only 0.08 . Therefore, a high overall technology preference ranking was governed primarily by good Opportunities, low Costs and low Risks. As a result, gasification turned out to be the most favoured technology for the UK as it does not require large land areas, has high government funding opportunities and has lower hygiene and environmental risks in comparison to other $\mathrm{WtE}$ technologies. The strong preference for gasification does not represent the current development status of the UK gasification market as there is only one operational MSW gasification plant. Although some large scale plants exist in Europe, North America and Japan (Defra, 2013b), successful applications of gasification-based WTE plants with continuous operation are so far limited in the world due to cost and reliability issues (Arena, 2011). Nevertheless, the situation in the UK may change in the future as there are a number of plants under construction and in the planning phase of development (UKWIN, 2015).

The results observed in this study highlight the significant variations in preference for alternative WtE technologies in different countries. This outcome is a result of the different socio-economic and technological environments which have been considered by the decision makers during the allocation of criteria weightings for each case study. Some of the main differences arose in the Benefits, Opportunities and Risks groups for India and the UK, and they included technology compatibility with local MSW composition, government funding opportunities, health and safety risks and the availability of technical expertise. Such differences are sometimes overlooked by stakeholders when making decisions and thus, more structured approaches need to be adopted.

One of the limitations of this study is that different evaluation criteria could have been incorporated. Selection criteria need to be carefully considered and often may be country specific. To address this, 
additional stakeholders and experts can be engaged when determining suitable selection criteria. Bringing a panel of experts together in a workshop makes it easier to achieve a group consensus. In this study, only academic experts' opinions were collected; however, municipal officers, policy makers and industry operators would likely have varying opinions. In order to account for these variations it is necessary to carry out a sensitivity analysis.

\section{Sensitivity analysis}

The sensitivity of the AHP-BOCR results was investigated to observe how the results may change according to different expert opinions and scenarios. The BOCR group importance weightings were each individually, increased and decreased whilst keeping the other group weightings proportionally the same (see Figure $8 \mathrm{a}-\mathrm{b}$ and Figure 9). A further sensitivity analysis was performed at the sub criteria level to examine the impact of potential changes in the WtE industry such as (i) improved MSW segregation practices in India, and (ii) reduced government funding for gasification in the UK.

For the case study in India, $\mathrm{AD}$ remains as the highest ranked technology regardless of individual BOCR group weightings. However, gasification's ranking is particularly sensitive to changes in the group weightings. As shown in Figure 8, the preference ranking for gasification decreases when the priority of Opportunities decreases and when the priority of Risk increases above 0.5 . For the UK case study, the most preferred technology (gasification) changes with variations in Costs group priority weightings. When the importance of Costs increases by more than $0.5, \mathrm{AD}$ has the potential to become more preferable than gasification (see Figure 9).

To investigate the outcome of potentially improved future MSW segregation practices in India, the priority rating for 'inadequate waste segregation' in the sub-criteria level was lowered from 0.433 to 0.233. This results in sanitary LFG emerging as the technology with the highest Risk rating. The scenario of reduced financial support for gasification in the UK was investigated by making the 
'government support' (Opportunities sub-criteria) priority weighting for gasification equal to that of AD's. This assumes that both technologies are eligible to equal amounts of financial support and also results in $\mathrm{AD}$ becoming the preferred technology. The analysis does indicate the model to be very sensitive to changes in the criteria weighting. Whilst, some extreme weightings have been considered, the results do highlight the importance of obtaining quality information and a consensus from a panel of experts.

\section{Conclusion}

The success of a WtE project is highly dependent on a country's socio-economic and technological environment. This study applied a MCDM method to compare the feasibility of five technologies for energy generation from MSW in a developing country (India) and a developed country (UK). Based on the results of this study, $\mathrm{AD}$ is the most promising technology for India to pursue. Gasification and RDF incineration are indicated to be the second and third most preferred technologies for India. For the UK, the results indicated gasification to be the most favourable technology; $\mathrm{AD}$ received the second highest preference. This is an interesting result as incineration is far more widely adopted and technical difficulties have hindered the uptake of gasification projects in the UK. As this study does not focus on a particular location within a country, a combination of the preferred $\mathrm{WtE}$ technologies is recommended for each country. Our results also highlighted the wide differences - particularly when considering the Benefits, Opportunities and Risks - in preference for the alternative WtE technologies in India and the UK, and these differences are at times omitted due to the lack of systematic decision making by stakeholders.

The research approach adopted in this study has produced informative results to help guide strategic decision makers for the selection of WtE technologies in a developing country and a developed country. Therefore, the AHP-BOCR model is considered as a valuable tool for the evaluation of waste management and sustainable energy generation technologies. It is suggested that the 
application of the AHP-BOCR model is used to evaluate other waste to energy generation technologies in different countries.

\section{Figures and Tables}

Figure 1a-b: Comparison of average MSW compositions in (a) India and (b) UK (Defra, 2009; EAI, 2013).

Figure 2: Hierarchical representation of the AHP-BOCR analysis.

Figure 3: Overview of MSW to energy conversion technologies and their outputs.

Figure 4: AHP-BOCR hierarchy structure with weightings obtained from experts' opinions.

Figure 5a-d: MSW WtE technology (a) Benefits, (b) Opportunities, (c) Costs, and (d) Risks preference rankings for both India and UK

Figure 6: WtE technology overall BOCR preference rankings for India based on $\mathrm{bB}+\mathrm{oO}-\mathrm{cC}-\mathrm{rR}$.

Figure 7: WtE technology overall BOCR preference rankings for UK based on $\mathrm{bB}+\mathrm{oO}-\mathrm{cC}-\mathrm{rR}$.

Figure 8a-b: Overall preference rankings in India with regard to (a) Opportunities priority weighting and (b) Risks priority weighting.

Figure 9: Overall preference rankings in UK with regard to Costs priority weighting.

Table 1: BOCR sub-criteria determined through the technology review.

Table 2: WtE BOCR data for India.

Table 3: WtE BOCR data for UK.

\section{References}

Ahmad, S., Tahar, R.M., 2014. Selection of renewable energy sources for sustainable development of electricity generation system using analytic hierarchy process: A case of Malaysia. Renew. Energy 63, 458-466. http://dx.doi.org/10.1016/j.renene.2013.10.001

Aragonés-Beltrán, P., Chaparro-González, F., Pastor-Ferrando, J., Pla-Rubio, A., 2014. An AHP (Analytic Hierarchy Process)/ANP (Analytic Network Process)-based multi-criteria decision approach for the selection of solar-thermal power plant investment projects. Energy 66, 222-238. http:/dx.doi.org/10.1016/j.energy.2013.12.016 
Aravossis, K., Anagnostopoulos, P., Koungolos, A., Vliamos, S., 2001. A new methodology approach for the technical-economical evaluation of alternative waste disposal methods by use of multi criteria analysis. In: Proceedings of the $7^{\text {th }}$ International Conference on Environmental Science and Technology, pp. 40-51.

Arena, U., 2011. Gasification: An alternative solution for waste treatment with energy recovery. Waste Manage., 31, 405-406. http://dx.doi.org/10.1016/j.wasman.2010.12.006

Arena, U., 2012. Process and technological aspects of municipal solid waste gasification. A review, Waste Manage., 32 (4), 625-639. http://dx.doi.org/10.1016/j.wasman.2011.09.025

Arena, U., Ardolino, F., Gregorio, F.G., 2015. A life cycle assessment of environmental performances of two combustion- and gasification-based waste-to-energy technologies, Waste Manage. 41, 60-74. http://dx.doi.org/10.1016/j.wasman.2015.03.041

ARUP, 2011. Review of the generation costs and deployment potential of renewable electricity technologies in the UK. Department of Energy and Climate Change.

ARUP, 2015. UK Energy Legislation Timeline.

http $/ /$ publications. arup.com/Publications/U/UK_Energy_Legislation_Timeline.aspx (accessed 10.01.15)

Asnani, P.U., 2006. India Infrastructure Report 2006: 8. Solid Waste Management.

http//www.iitk.ac.in/3inetwork/html/reports/IIR2006/Solid_Waste.pdf (accessed 18/06/2015)

Aswani, S., 2012. Waste to Energy in India. Energetica India. , 53-55. http://www.energeticaindia.net/magazine/june-2012 (accessed 20.07.2014)

Atmaca, E., Basar, H.B., 2012. Evaluation of power plants in Turkey using Analytic Network Process (ANP). Energy 44, 555-563. http://dx.doi.org/10.1016/j.energy.2012.05.046

Banar, M., Kose, B., Ozkan, A., Poyraz Acar, I., 2007. Choosing a municipal landfill site by analytic network process. Environ. Geol. 52, 747-751.http://dx.doi.org/10.1007/s00254-006-0512-x

Bove, B., Lunghi, P., 2006. Electric power generation from landfill gas using traditional and innovative technologies, Energy Convers. Manage., 47 (11-12), 1391-1401.

http//dx.doi.org/10.1016/j.enconman.2005.08.017

Brans, J.P., Vincke, P., Mareschal, B., 1986. How to select and how to rank projects: The Promethee method. Eur. J. Oper. Res. 24, 228-238. http//dx.doi.org/10.1016/0377-2217(86)90044$\underline{5}$

Chakraborty, M., Sharma, C., Pandey, J., Gupta, P.K., 2013. Assessment of energy generation potentials of MSW in Delhi under different technological options. Energy Convers. Manage. 75, 249-255. http//dx.doi.org/10.1016/j.enconman.2013.06.027

Chen, H.H., Kang, H., Lee, A.H.I., 2010. Strategic selection of suitable projects for hybrid solarwind power generation systems. Renew. Sustain. Energy Rev. 14, 413-421.

http//dx.doi.org/10.1016/j.rser.2009.08.004 
CPHEEO, 2000. Manual on Municipal Solid Waste Management, Central Public Health and Environmental Engineering Organisation, Ministry of Urban Development, Government of India.

De Feo, G., De Gisi, S., 2010. Using an innovative criteria weighting tool for stakeholders involvement to rank MSW facility sites with the AHP. Waste Manage. 30, 2370-2382. http//dx.doi.org/10.1016/j.was man.2010.04.010

DECC, 2014. Digest of United Kingston Energy Statistics 2014. Department of Energy and Climate Change.

Defra, 2009. Municipal Waste Composition: Review of Municipal Waste Component Analyses. Department for Environment, Food and Rural Affairs.

Defra, 2013a. Incineration of Municipal Solid Waste. Department for Environment, Food and Rural Affairs.

Defra, 2013b. Advanced Thermal Treatment of Municipal Solid Waste. Department for Environment, Food and Rural Affairs.

Defra, 2013c. Anaerobic Digestion Strategy and Action Plan. Department for Environment, Food and Rural Affairs.

Defra, 2014a. Energy from Waste: A guide to the debate. Department for Environment, Food and Rural Affairs.

Defra, 2014b. Refuse derived fuel market in England. Defra response to the call for evidence. Department for Environment, Food and Rural Affairs.

Dey, P.K., Ghosh, S.K., Nixon, J., 2014. Characteristics, issues and challenges of municipal solid waste (MSW) to energy supply chain: comparative analys is of India and the UK. In: Proceedings of the $4^{\text {th }}$ International Conference on Solid Waste Management. pp. 389-397.

EAI, 2013. India MSW to Energy: Status, Opportunities and Bottlenecks. Energy Alternatives India. http:/www.eai.in/ref/wp/india-msw-to-energy.html (accessed 31.05.2014)

Evangelisti, S., Tagliaferri, C., Clift, R., Lettieri, P., Taylor, R., Chapman, C., 2015. Life cycle assessment of conventional and two-stage advanced energy-from-waste technologies for municipal solid waste treatment, J. Clean. Prod., 100, 212-223. http://dx.doi.org/10.1016/j.jclepro.2015.03.062

Fitzgerald, G.C., 2013. 5 - Pre-processing and treatment of municipal solid waste (MSW) prior to incineration, in Klinghoffer, N.B., Castaldi, M.J. (Eds.), Waste to Energy Conversion Technology. Woodhead Publishing, pp. 55-71. http//dx.doi.org/10.1533/9780857096364.2.55

Ghosh, S.K., 2014. Paradigm shift for a total waste management in developing in India. In: Proceedings of the $4^{\text {th }}$ International Conference on Solid Waste Management. pp. 3-12.

Greater London Authority, 2008. Costs of Incineration and non-incineration energy-from-waste technologies.

http//legacy.london.gov.uk/mayor/environment/waste/docs/efwtechnologiesreport.pdf (accessed 18.09.2014) 
Hartmann, H., Ahring, B.K., 2005. Anaerobic digestion of the organic fraction of municipal solid waste: Influence of co-digestion with manure. Water Res. 39, 1543-1552.

http//dx.doi.org/10.1016/j. watres.2005.02.001

HMRC, Rates and allowances: Landfill Tax. HM Revenue and Customs. 2014.

https://www.gov.uk/government/publications/rates-and-allowances-landfill-tax/rates-andallowances-landfill-tax (accessed 09.11.2014)

Hokkanen, J., Salminen, P., 1997. Choosing a solid waste management system using multicriteria decision analysis. Eur. J. Oper. Res. 98, 19-36. http://dx.doi.org/10.1016/0377-2217(95)00325-8

Hoornweg, D., Bhada-Tata, P., 2012. What a waste - A Global Review of Solid Waste Management. World Bank, Washington DC, USA.

Hsu, P., Wu, C., Li, Y., 2008. Selection of infectious medical waste disposal firms by using the analytic hierarchy process and sensitivity analysis. Waste Manage. 28, 1386-1394.

http:/dx.doi.org/10.1016/j.wasman.2007.05.016

Hwang, C., Yoon, K., 1981. Multiple Attribute Decision Making: Methods and Applications. Springer-Verlag, New York.

Iacovidou, E., Vlachopoulou, M., Mallapaty, S., Ohandja, D.G., Gronow, J., Voulvoulis, N., 2013. Anaerobic digestion in municipal solid waste management: Part of an integrated, holistic and sustainable solution. Waste Manage. 33, 1035-1036.

http//dx.doi.org/10.1016/j.wasman.2013.03.010

IEA Bioenergy, 2012. The municipal solid waste resource in England. http//www.ieabioenergytask36.org (accessed 05.06.2014)

IEA, 2013. Renewable Energy Medium-Term Market Report. International Energy Agency.

IRENA, 2012. Renewable energy technology: cost analysis series - biomass for power generation. International Renewable Energy Agency.

Jamasb, T., Nepal, R., 2010. Issues and options in waste management: A social cost-benefit analysis of waste-to-energy in the UK. Resour. Conserv. Recycling 54, 1341-1352.

http//dx.doi.org/10.1016/j.resconrec.2010.05.004

Kalyani, K.A., Pandey, K.K., 2014. Waste to energy status in India: A short review. Renew . Sustain. Energy Rev. 31, 113-120. http//dx.doi.org/10.1016/j.rser.2013.11.020

Keeney, R.L., Raiffa, H., 1993. Decisions with Multiple Objectives: Preferences and Value Tradeoffs. Cambridge University Press, New York.

Kelkar, K., 2013. The Indian Express: Pollution level near Okhla waste-to-energy plant 25 times above limit. 2014. http://archive.indianexpress.com/news/pollution-level-near-okhla-wastetoenergyplant-25-times-above-limit/1124718/ (accessed 03.09.2014)

Kumar, A., Sharma, M.P., 2014. Estimation of GHG emission and energy recovery potential from MSW landfill sites. Sustain. Energy Technol. Assess. 5, 50-61.

http:/dx.doi.org/10.1016/j. seta.2013.11.004 
Kumar, V.N, Kumar, M.S., 2014. Bioenergy from Sanitary landfill gas - A Resource with Economic and Environmental benefits. Int. J. ChemTech Res. 6, 2484-2492.

Lee, A.H.I., Chen, H.H., Kang, H., 2009. Multi-criteria decision making on strategic selection of wind farms. Renew. Energy 34, 120-126. http://dx.doi.org/10.1016/j.renene.2008.04.013

Løken, E., 2007. Use of multicriteria decision analysis methods for energy planning problems. Renew. Sustain. Energy Rev. 11, 1584-1595. http//dx.doi.org/10.1016/j.rser.2005.11.005

Lombardi, L., Carnevale, E., Corti, A., 2015. A review of technologies and performances of thermal treatment systems for energy recovery from waste, Waste Manage., 37, $26-44$.

http:/dx.doi.org/10.1016/j.wasman.2014.11.010

Mallapaty, S.F., 2011. Lessons from Europe: The suitability of anaerobic digestion technologies for municipal solid waste management in the UK.

https://work space.imperial.ac.uk/environmentalpolicy/Public/Executive\%20Summaries\%2020102011/WM/Mallapaty, \%20Smriti.pdf (accessed 06.07.2014)

Massarutto, A., 2015. Economic aspects of thermal treatment of solid waste in a sustainable WM system, Waste Manage. 37, 45-57.http://dx.doi.org/10.1016/j.wasman.2014.08.024

Mazumdar, N., 2008. MSW to energy in India: the scenario and expectations. IL \& FS Waste Management \& Urban Services Ltd.

http//www.setatwork.eu/events/slides/india/nbmazumdar_fp6.pdf (accessed 12.08.2014)

Murphy, J.D., McKeogh, E., 2004. Technical, economic and environmental analysis of energy production from municipal solid waste. Renew. Energy 29, 1043-1057.

http:/dx.doi.org/10.1016/j.renene.2003.12.002

Nixon, J.D., Dey, P.K., Ghosh, S.K., Davies, P.A., 2013b. Evaluation of options for energy recovery from municipal solid waste in India using the hierarchical analytical network process. Energy 59, 215-223. http://dx.doi.org/10.1016/j.energy.2013.06.052

Nixon, J.D., Wright, D.G., Dey, P.K., Ghosh, S.K., Davies, P.A., 2013a. A comparative assessment of waste incinerators in the UK. Waste Manage. 33, 2234-2244.

http:/dx.doi.org/10.1016/j. was man.2013.08.001

NRI. 2012. Policies for renewable energies/biomass in India. Renewable energy policy. India: The Energy and Resources Institute (TERI)Pohekar, S.D., Ramachandran, M., 2004. Application of multi-criteria decision making to sustainable energy planning-A review. Renew. Sustain. Energy Rev. 8, 365-381. http://dx.doi.org/10.1016/j.rser.2003.12.007

Rand, T., Haukohl, J., Marxen, U., 2000. Municipal Solid Waste Incineration - A Decision Makers Guide. World Bank, Washington DC, USA.

Richardson, Y., Blin, J., Julbe, A., 2012. A short overview on purification and conditioning of syngas produced by biomass gasification: Catalytic strategies, process intensification and new concepts, Prog. Energy Combust. Sci., 38, (6) 765-781.

http//dx.doi.org/10.1016/j.pecs.2011.12.001 
Roy, B., 1991. The outranking approach and the foundations of electre methods. Theory Decis. 31, 49-73. http://dx.doi.org/10.1007/BF00134132

Saaty, T.L, 2004. Fundamentals of the analytic network process - multiple networks with benefits, costs, opportunities and risks. J. Syst. Sci. Syst. Eng. 13, 348-379.

http:/dx.doi.org/10.1007/s11518-006-0171-1

Saaty, T.L., 1977. A scaling method for priorities in hierarchical structures. J. Math. Psychol. 15, 234-281. http:/dx.doi.org/10.1016/0022-2496(77)90033-5

Saaty, T.L., 1980. The Analytic Hierarchy Process: Planning, Priority Setting, Resource Allocation. McGraw-Hill.

Saaty, T.L., 2001. Decision Making with Dependence and Feedback: The Analytic Network Process: The Organization and Prioritization of Complexity, 2 ed. Rws Publications.

Saaty, T.L., Sodenkamp, M., 2010. The Analytic Hierarchy and Analytic Network Measurement Processes: The Measurement of Intangibles, in Zopounidis, C., Pardalos, P.M. (Eds.), Handbook of Multicriteria Analysis. Springer Berlin Heidelberg, Berlin, pp. 91-166.

Scott, J.A., Ho, W., Dey, P.K., 2012. A review of multi-criteria decision-making methods for bioenergy systems. Energy 42, 146-156. http://dx.doi.org/10.1016/j.energy.2012.03.074

Sharholy, M., Ahmad, K., Mahmood, G., Trivedi, R.C., 2008. Municipal solid waste management in Indian cities - A review. Waste Manage. 28, 459-467.

http//dx.doi.org/10.1016/j.was man.2007.02.008

Siddiqui, F.Z., Khan, M.D., 2011. Landfill gas recovery and its utilization in India: Current status, potential prospects and policy implications. J. Chem. Pharm. Res. 3.

Singh, R.P., Tyagi, V.V., Allen, T., Ibrahim, M.H., Kothari, R., 2011. An overview for exploring the possibilities of energy generation from municipal solid waste (MSW) in Indian scenario. Renew. Sustain. Energy Rev. 15, 4797-4808. http//dx.doi.org/10.1016/j.rser.2011.07.071

Soltani, A., Hewage, K., Reza, B., Sadiq, R., 2015. Multiple stakeholders in multi-criteria decisionmaking in the context of Municipal Solid Waste Management: A review. Waste Manage. 35, 318328. http://dx.doi.org/10.1016/j.wasman.2014.09.010

Stein, E.W., 2013. A comprehensive multi-criteria model to rank electric energy production technologies. Renew. Sustain. Energy Rev. 22, 640-654.

http//dx.doi.org/10.1016/j.rser.2013.02.001

Tanigaki, N., Ishida, Y., Osada, M., 2015. A case-study of landfill minimization and material recovery via waste co-gasification in a new waste management scheme, Waste Manage., 37, 137146. http://dx.doi.org/10.1016/j.wasman.2014.07.024

Tanigaki, N., Manako, K., Osada, M., 2012. Co-gasification of municipal solid waste and material recovery in a large-scale gasification and melting system, Waste Manage., 32, (4) 667-675.

http//dx.doi.org/10.1016/j. wasman.2011.10.019 
UKWIN, 2015. Table of Potential, Existing and Prevented Incinerators.

http:/ukwin.org.uk/resources/table/ (accessed 22.06.15)

UNFCCC, 2006. Clean Development Mechanism Project Design Document Form (CDM-PDD) https:/cdm. unfccc.int/filestorage/I/9/P/I9PM2CX4HWDR1 U86T0ALZN7VOS3E5F/PDD\%20Vers ion\%203.pdf?t=eFV8bnJ3MjVzfDCVxBdRnPR8mPhx-jZASZRn (accessed 15.06.15)

Unnikrishnan, S., Singh, A., 2010. Energy recovery in solid waste management through CDM in India and other countries. Resour. Conserv. Recycling 54, 630-640.

http//dx.doi.org/10.1016/j.resconrec.2009.11.003

Wang, J., Jing, Y., Zhang, C., Zhao, J., 2009. Review on multi-criteria decision analysis aid in sustainable energy decision-making. Renew. Sustain. Energy Rev. 13, 2263-2278.

http://dx.doi.org/10.1016/j.rser.2009.06.021

Wong, D., Tam, S., 2014. Thermal waste treatment in the European Union. http $/ /$ www.legco.go v.hk/yr13-14/english/sec/library/1314in12-e.pdf (accessed 15.08.2014)

World Energy Council, 2013a. World Energy Resources: Waste to Energy.

World Energy Council, 2013b. World Energy Perspective, Cost of Energy Technologies Project.

WRAP, 2012. EfW Development Guidance: Financial Incentives. Waste \& Resources Action Programme.

WRAP, 2013. List of energy from waste sites. Waste \& Resources Action Programme. http $/ /$ www.wrap.org.uk/node/15031 (accessed 10.06.2014)

WRAP, 2014. Gate Fees Report 2014: Comparing the costs of alternative waste treatment options. Waste \& Resources Action Programme.

Yi, S., Sin, H., Heo, E., 2011. Selecting sustainable renewable energy source for energy assistance to North Korea. Renew. Sustain. Energy Rev. 15, 554-563.

Zhou, P., Ang, B.W., Poh, K.L., 2006. Decision analysis in energy and environmental modeling: An update. Energy 31, 2604-2622. http//dx.doi.org/10.1016/j.energy.2005.10.023

Zhu, D., Asnani, P.U., Zurbrügg, C., Anapolsky, S., Mani, S., 2007. Improving Municipal Solid Waste Management in India. The World Bank, Washington, DC. http://dx.doi.org/10.1596/978-0$\underline{8213-7361-3}$

Zoffer, J., Bahurmoz, A., Hamid, M., Minutolo, M., Saaty, T., 2008. Synthesis of Complex Criteria Decision Making: A Case Towards a Consensus Agreement for a Middle East Conflict Resolution. Group Decis. Negotiation 17, 363-385. http://dx.doi.org/10.1007/s10726-008-9104-3 
Figure 1

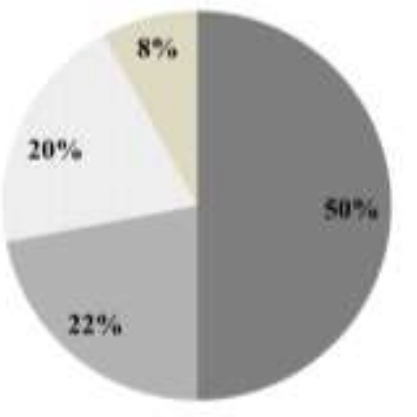

(a) Indiu

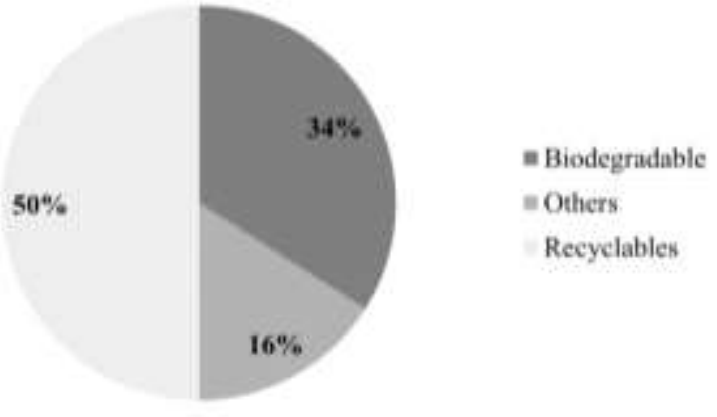

(b) UK 
Figure 2

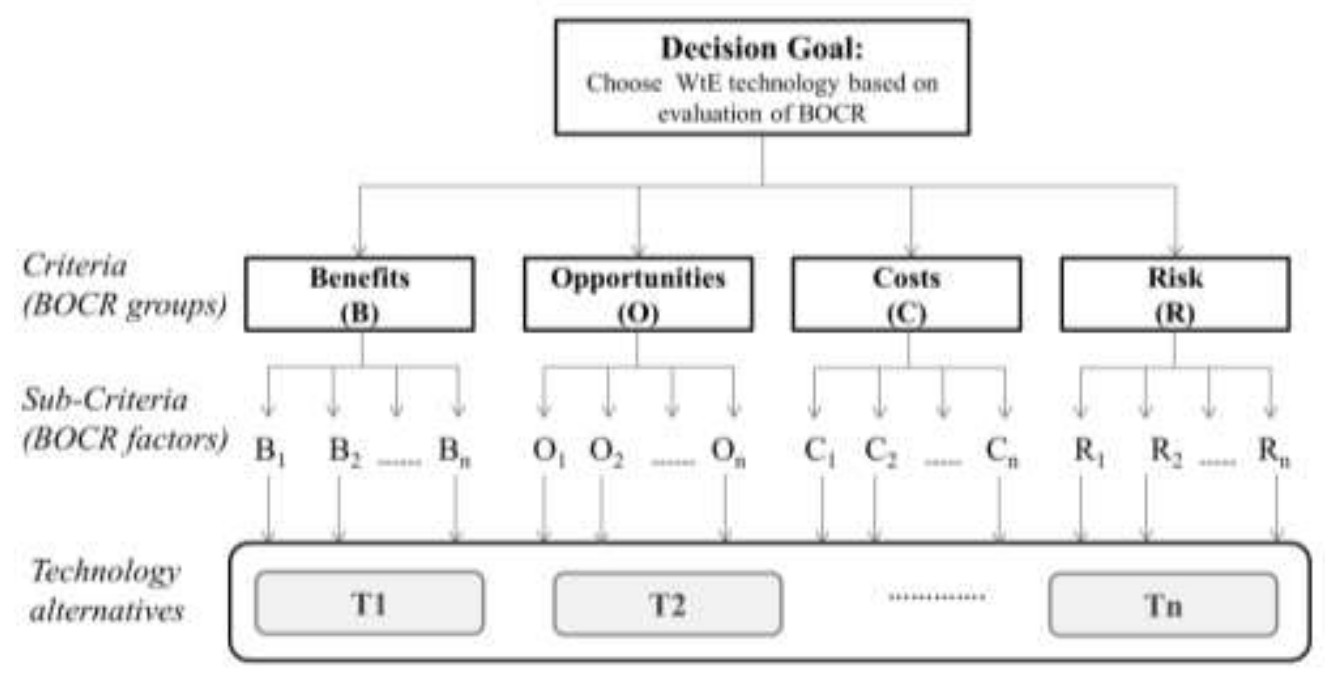


Figure 3

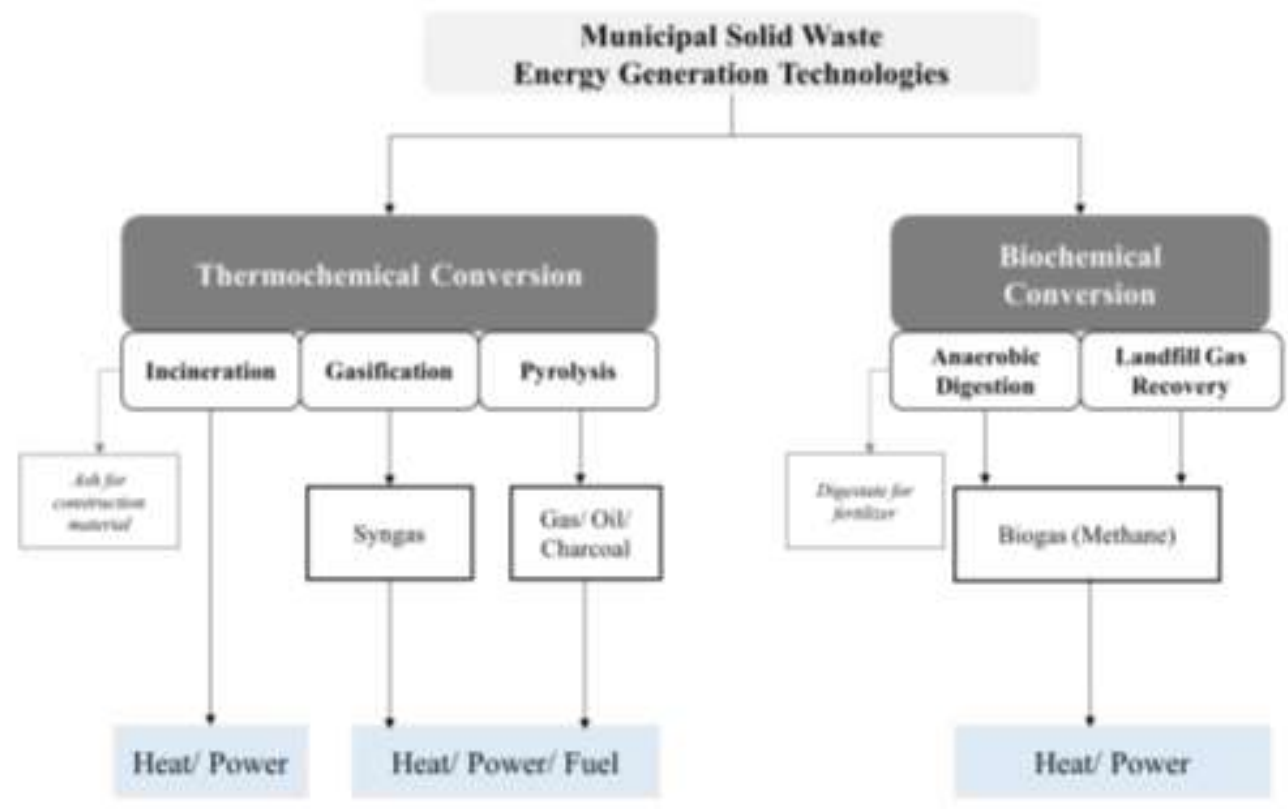


Figure 4

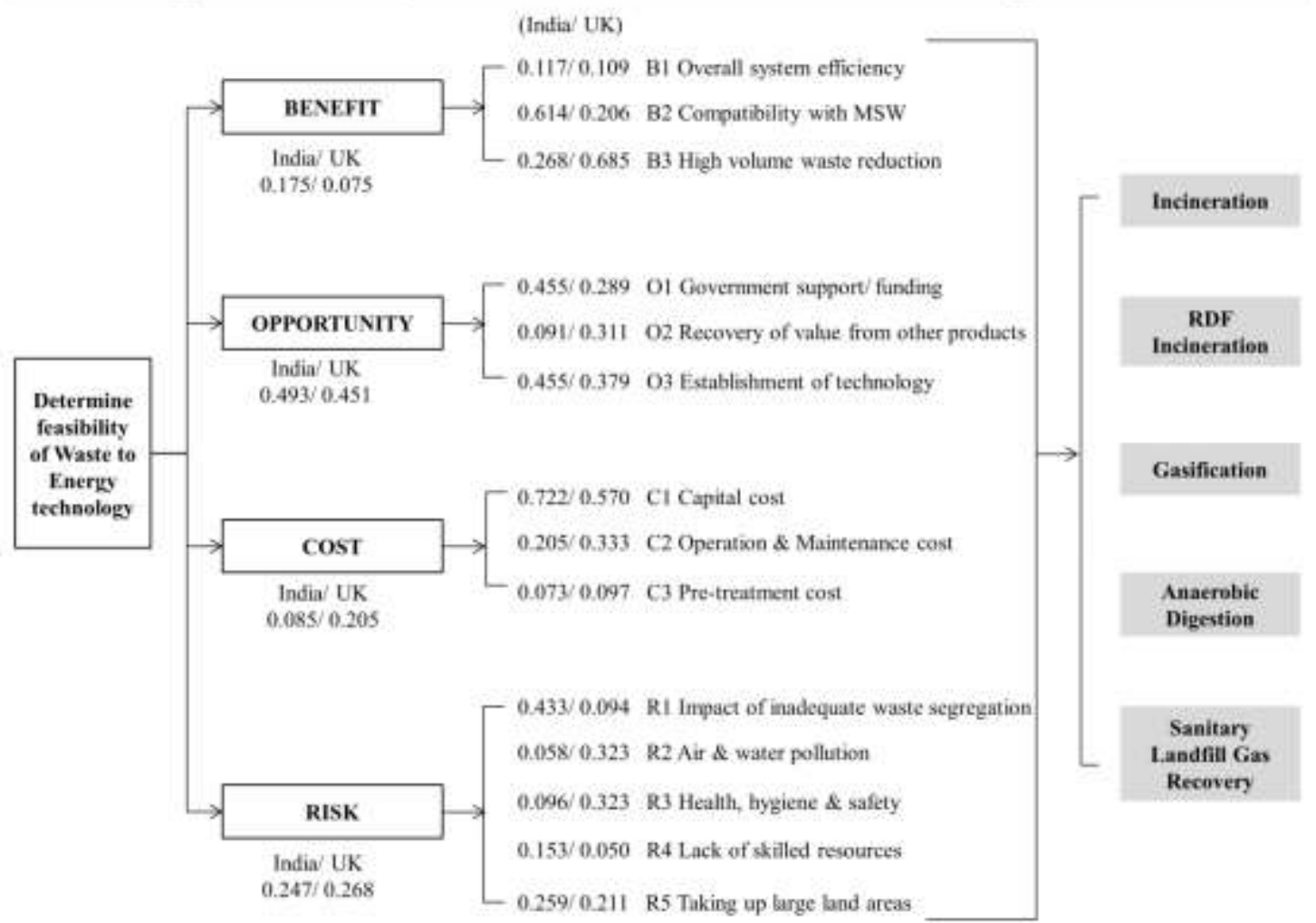


Figure 5

(a) Benefits

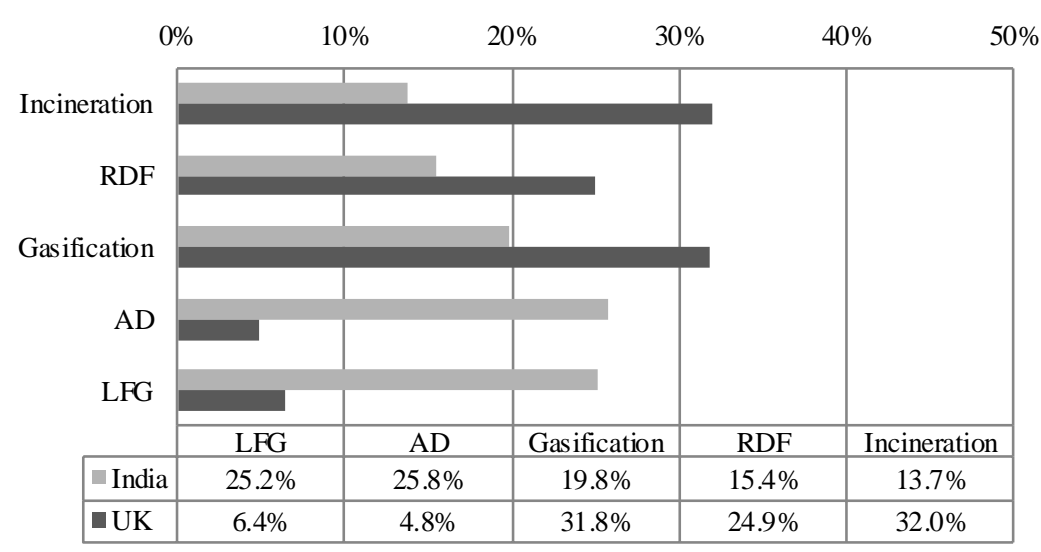

\section{(c) Costs}

Priority Ranking

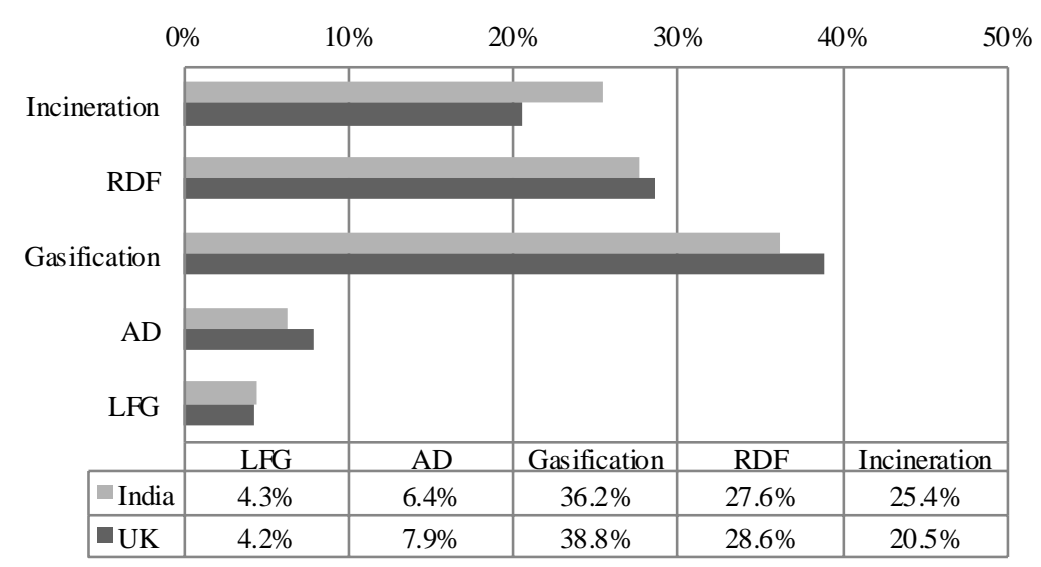

\section{(b) Opportunities Priority Ranking}

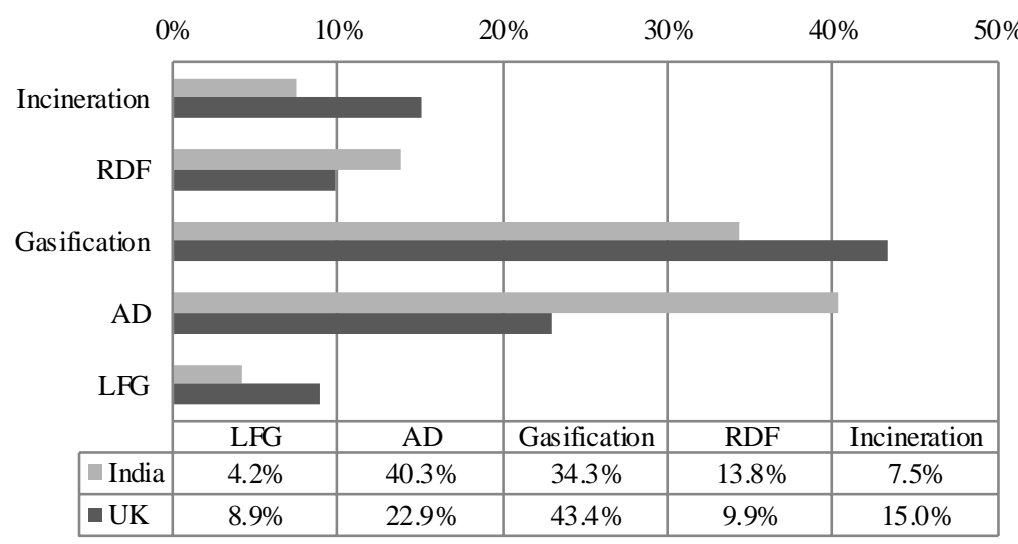

(d) Risks

Priority Ranking

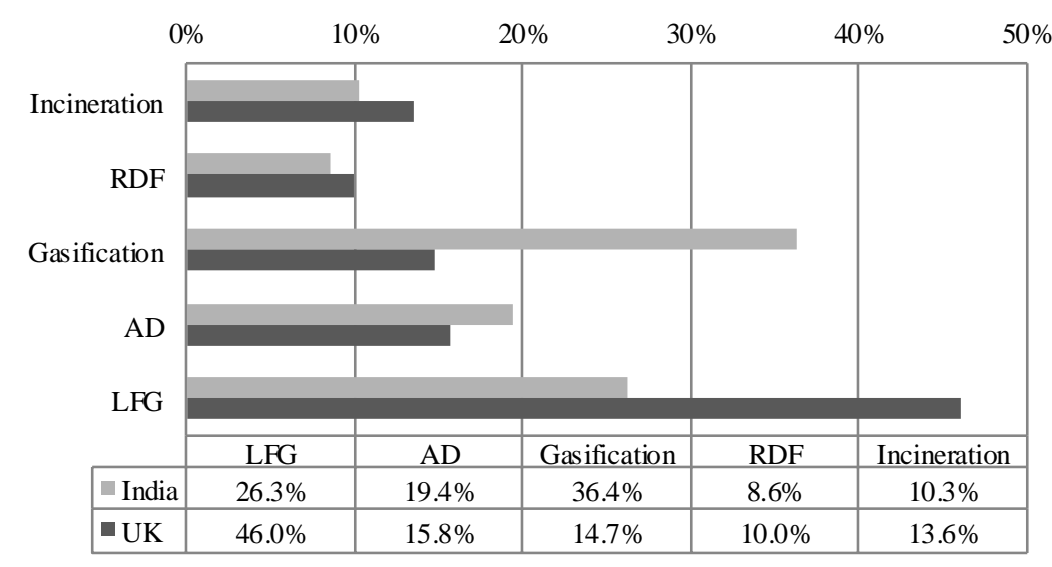


Figure 6

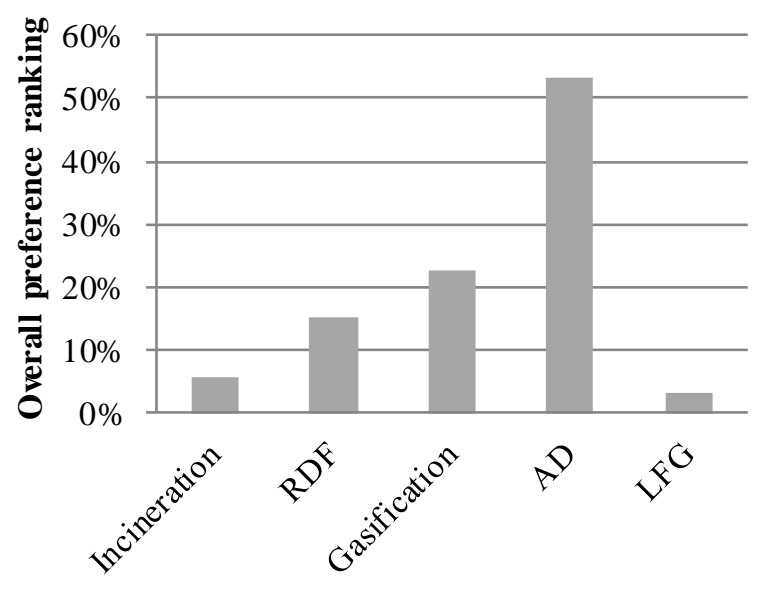


Figure 7

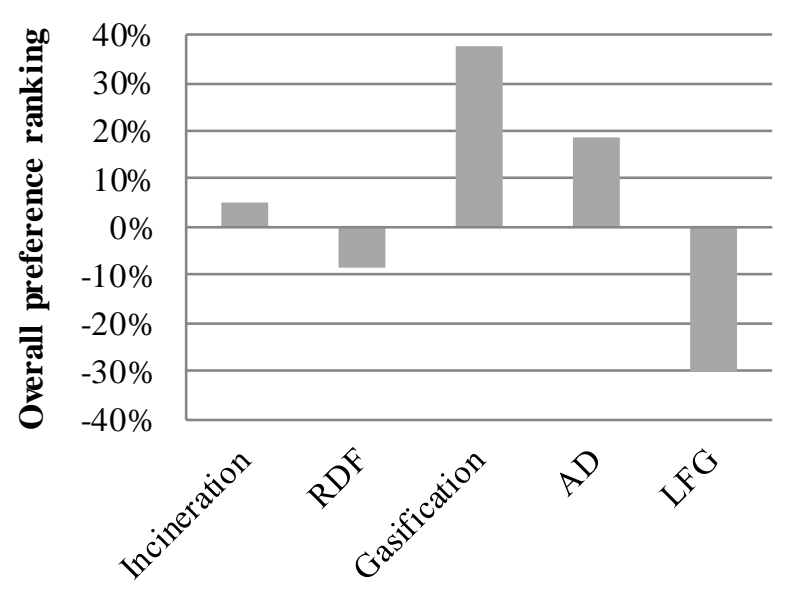


Figure 8
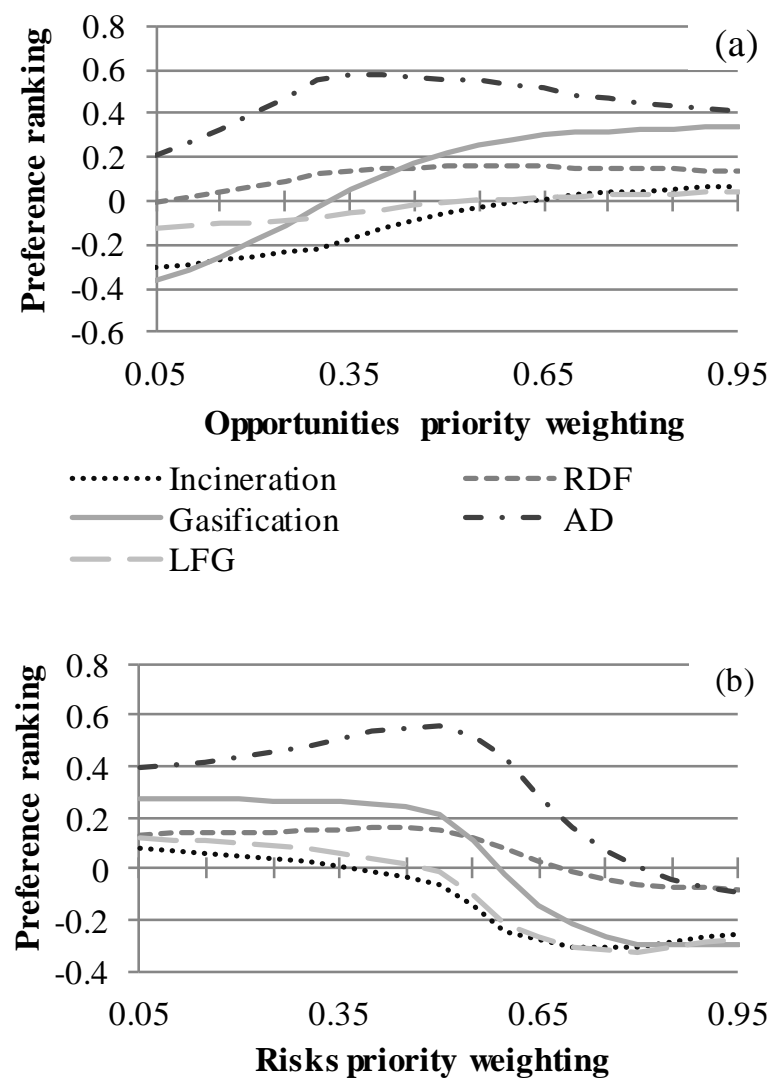

$\begin{array}{ll}\cdots \cdots \cdot \text { Incineration } & \cdots-\infty \text { RDF } \\ - \text { Gasification } & -\cdots-\text { AD } \\ - \text { LFG } & \end{array}$


Figure 9

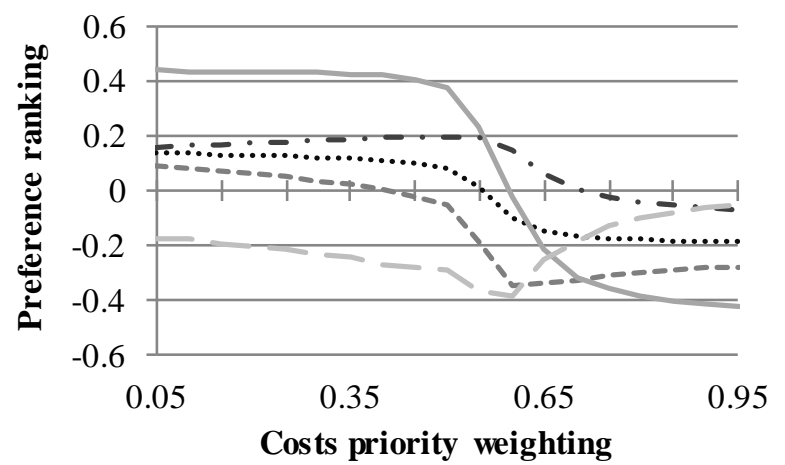

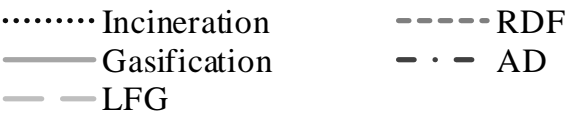


Table 1

\begin{tabular}{|c|c|}
\hline BOCR group & Sub-crite ria \\
\hline \multirow{3}{*}{ Benefit (B) } & B1 Overall system efficiency \\
\hline & $\begin{array}{l}\text { B2 Compatibility with local Municipal Solid } \\
\text { Waste (MSW) composition }\end{array}$ \\
\hline & B3 Volume reduction of MSW \\
\hline \multirow{3}{*}{ Opportunity (O) } & O1 Government support/funding \\
\hline & O2 Recovery of value from other products \\
\hline & O3 Prominence/ establishment of technology \\
\hline \multirow{3}{*}{$\operatorname{Cost}(\mathrm{C})$} & C1 Capital cost \\
\hline & C2 Operation and Maintenance (O\&M)cost \\
\hline & C3 Pre-treatment cost \\
\hline \multirow{5}{*}{ Risk (R) } & R1 Impact of inadequate waste segregation \\
\hline & R2 Air pollution \& water pollution \\
\hline & R3 Health \& safety/hygiene risk \\
\hline & $\begin{array}{l}\text { R4 Lack of skilled resources/technical } \\
\text { expertise }\end{array}$ \\
\hline & R5 Take up of large land area \\
\hline
\end{tabular}


Table 2

\begin{tabular}{|c|c|c|c|c|c|}
\hline \multirow[b]{2}{*}{ BOCR } & \multicolumn{5}{|c|}{ Waste to energy technology type } \\
\hline & Incineration & RDF Incineration & Gasification & Anae robic Digestion & $\begin{array}{c}\text { Landfill Gas } \\
\text { Recovery }\end{array}$ \\
\hline \multicolumn{6}{|l|}{ BENDFIIS } \\
\hline$O$ ve rall system efficiency & $18 \%-26 \%$ & $\begin{array}{c}\text { Potentially higher than } \\
\text { incineration }\end{array}$ & $18 \%-30 \%$ & $10-20 \%$ & $10 \%$ \\
\hline $\begin{array}{l}\text { Compatible with local MSW } \\
\text { composition }\end{array}$ & Low & Medium & Medium & High compatibility & High compatibility \\
\hline Volume reduction of MSW & $90 \%$ & $\begin{array}{l}\text { Similar for RDF } \\
\text { fraction of MSW }\end{array}$ & $50-90 \%$ & $\begin{array}{c}\text { up to } 38 \% \\
\text { (75\% OFMSW) }\end{array}$ & Low \\
\hline \multicolumn{6}{|l|}{ OPPORTUNITIIES } \\
\hline $\begin{array}{l}\text { Generation/recovery of } \\
\text { othervaluable products }\end{array}$ & $\begin{array}{l}\text { Low recovery } \\
\text { of metals }\end{array}$ & Low recovery of metals & $\begin{array}{l}\text { Production of fuel gas/ } \\
\text { oil; slag and ash } \\
\text { potential as aggregate }\end{array}$ & $\begin{array}{l}\text { Commercial fertiliser } \\
\text { from digestate }\end{array}$ & None \\
\hline $\begin{array}{l}\text { Government support/ } \\
\text { funding }{ }^{\mathrm{a}}\end{array}$ & None & $\begin{array}{c}\text { National Programme } \\
\text { on Energy Recovery, } \\
230,000 \$ / \mathrm{MW}\end{array}$ & $\begin{array}{c}\text { National Programme } \\
\text { on Energy Recovery, } \\
610,000 \$ / \mathrm{MW}\end{array}$ & $\begin{array}{c}\text { National Programme on } \\
\text { Energy Recovery, } \\
310,000 \$ / \mathrm{MW} \\
\end{array}$ & None \\
\hline $\begin{array}{l}\text { Technology prominence/ } \\
\text { establishment }\end{array}$ & $\begin{array}{c}\text { Low } \\
\text { prominence }\end{array}$ & Emerging & Emerging & Most prominent & Low prominence \\
\hline \multicolumn{6}{|l|}{ COSTIS } \\
\hline Capital cost ${ }^{\mathrm{a}}$ & $155-250 \$ / \mathrm{tpa}$ & $135 \$ / \mathrm{tpa}$ & $170-300 \$ /$ tpa & $50 \$ / \mathrm{tpa}$ & $10 \$ / \mathrm{tpa}$ \\
\hline$O \& M^{a}$ & $85 \$ /$ tonne & $\begin{array}{l}\text { Higher compared to } \\
\text { incineration due to } \\
\text { processing of RDF }\end{array}$ & $65-112 \$ /$ tonne & $5-30 \$ /$ tonne & $0.2-0.3 \$ /$ tonne \\
\hline Pre-treatment costs & None & $\begin{array}{l}\text { Medium-High } \\
\text { (shredding, } \\
\text { pelletisation etc.) }\end{array}$ & $\begin{array}{l}\text { Medium-High } \\
\text { (segregation and } \\
\text { shredding) }\end{array}$ & $\begin{array}{c}\text { Medium-High } \\
\text { (segregation required) }\end{array}$ & $\begin{array}{l}\text { Medium (cost of } \\
\text { pre-treatment to } \\
\text { upgrade gas to } \\
\text { pipeline quality and } \\
\text { leachate treatment) }\end{array}$ \\
\hline \multicolumn{6}{|l|}{ RISKS } \\
\hline $\begin{array}{l}\text { Impact of inadequate waste } \\
\text { segregation }\end{array}$ & Low & Low & High & Medium & Low \\
\hline \multirow[b]{2}{*}{ Air \& Water Pollution } & $\begin{array}{c}0.22 \mathrm{~kg} \\
\mathrm{CO}_{2} / \mathrm{kWh}\end{array}$ & $\begin{array}{c}\text { Lower than } \\
\text { unprocessed MSW }\end{array}$ & $0.11 \mathrm{~kg} \mathrm{CO}_{2} / \mathrm{kWh}$ & $\begin{array}{c}\text { Net positive } \\
\text { environmental gains } \\
\text { achievable }\end{array}$ & $1-1.2 \mathrm{~kg} \mathrm{CO}_{2} / \mathrm{kWh}$ \\
\hline & $\begin{array}{l}\text { Medium water } \\
\text { pollution } \\
\text { (water used in } \\
\text { scrubbing) } \\
\end{array}$ & $\begin{array}{l}\text { Medium water } \\
\text { pollution } \\
\text { (water used in } \\
\text { scrubbing) } \\
\end{array}$ & $\begin{array}{l}\text { Small quantity waste } \\
\text { water to dispose of }\end{array}$ & $\begin{array}{l}\text { Medium water } \\
\text { pollution }\end{array}$ & $\begin{array}{l}\text { Medium-High water } \\
\text { pollution }\end{array}$ \\
\hline $\begin{array}{l}\text { Hygiene/ health \& safety } \\
\text { risks }\end{array}$ & $\begin{array}{l}\text { Hygienic. } \\
\text { Transmission } \\
\text { of disease } \\
\text { minimised (no } \\
\text { direct contact } \\
\text { with waste) }\end{array}$ & $\begin{array}{c}\text { Hygienic. Transmission } \\
\text { of disease minimised } \\
\text { (no direct contact with } \\
\text { waste) }\end{array}$ & $\begin{array}{c}\text { Hy gienic. Transmission } \\
\text { of disease minimised } \\
\text { (no direct contact with } \\
\text { waste) }\end{array}$ & $\begin{array}{l}\text { Pathogenic content of } \\
\text { feedstock may cause } \\
\text { health risks during } \\
\text { transport; potential } \\
\text { asphyxiation and } \\
\text { explosion hazard from } \\
\text { methane build up if not } \\
\text { well ventilated }\end{array}$ & $\begin{array}{l}\text { Infectious waste } \\
\text { from hospitals } \\
\text { might find way to } \\
\text { landfill site; } \\
\text { potential } \\
\text { asphyxiation and } \\
\text { explosion hazard } \\
\text { from methane build } \\
\text { up if not well } \\
\text { ventilated }\end{array}$ \\
\hline $\begin{array}{l}\text { Lack of resources/technical } \\
\text { expertise }\end{array}$ & $\begin{array}{l}\text { High - Lack of } \\
\text { highly skilled } \\
\text { expertise }\end{array}$ & $\begin{array}{l}\text { High - Lack of highly } \\
\text { skilled expertise }\end{array}$ & $\begin{array}{l}\text { High - Lack of highly } \\
\text { skilled expertise }\end{array}$ & $\begin{array}{l}\text { Low - skilled personnel } \\
\text { not required }\end{array}$ & $\begin{array}{c}\text { Medium - lack of } \\
\text { skilled expertise to } \\
\text { develop and } \\
\text { maintain sanitary } \\
\text { system } \\
\end{array}$ \\
\hline $\begin{array}{l}\text { Requirement of large land } \\
\text { area }\end{array}$ & 0.8 hectare & 0.8 hectare & 0.8 hectare & 2 hectares & 36 hectares \\
\hline
\end{tabular}

${ }^{\mathrm{a}}$ The 2015 exchange rate of 1 Indian Rupee (INR) to 0.016 USDollars (USD) has been used 
Table 3

\begin{tabular}{|c|c|c|c|c|c|c|}
\hline \multirow{2}{*}{\multicolumn{2}{|c|}{ BOCR }} & \multicolumn{5}{|c|}{ Waste to Energy technology type } \\
\hline & & Incineration & RDF Incineration & Gasification & Anaerobic Digestion & $\begin{array}{c}\text { Landfill Gas } \\
\text { Recovery }\end{array}$ \\
\hline \multicolumn{7}{|l|}{ B ENDEITS } \\
\hline \multicolumn{2}{|c|}{ O ve rall system efficiency } & $18 \%-26 \%$ & $\begin{array}{l}\text { Potentially higher } \\
\text { than incineration }\end{array}$ & $10 \%-40 \%$ & $10-20 \%$ & $10 \%$ \\
\hline \multicolumn{2}{|c|}{$\begin{array}{l}\text { Compatible with local } \\
\text { MSW composition }\end{array}$} & High compatibility & High compatibility & High compatibility & Low compatibility & Compatible \\
\hline \multicolumn{2}{|c|}{ Volume reduction of MSW } & $90 \%$ & $75-90 \%$ & $50-90 \%$ & $\begin{array}{l}\text { up to } 25 \%(75 \% \\
\text { OFMSW })\end{array}$ & Low \\
\hline \multicolumn{7}{|c|}{ OPPORIUNITIES } \\
\hline \multicolumn{2}{|c|}{$\begin{array}{l}\text { Generation of other } \\
\text { valuable by-products }\end{array}$} & $\begin{array}{c}\text { Recovery of metals, } \\
\text { bottom ash } \\
\text { potential as } \\
\text { aggregate for } \\
\text { construction }\end{array}$ & $\begin{array}{l}\text { Recovery of metals, } \\
\text { bottom ash potential } \\
\text { as aggregate for } \\
\text { construction }\end{array}$ & $\begin{array}{l}\text { Production of fuel } \\
\text { gas/ oil; slag and ash } \\
\text { potential as aggregate }\end{array}$ & $\begin{array}{l}\text { Potential market for } \\
\text { compost from source } \\
\text { separated waste }\end{array}$ & None \\
\hline \multirow{4}{*}{$\begin{array}{l}\text { Government } \\
\text { support/ } \\
\text { funding }\end{array}$} & ROC & $\begin{array}{l}1 \mathrm{ROC} / \mathrm{MWh} \\
\text { only if it is CHP }\end{array}$ & $\begin{array}{l}1 \mathrm{ROC} / \mathrm{MWh} \\
\text { only if it is } \mathrm{CHP}\end{array}$ & $2 \mathrm{ROCs} / \mathrm{MWh}$ & $2 \mathrm{ROCs} / \mathrm{MWh}$ & $\begin{array}{l}\text { Open sites Zero } \\
\text { ROCs/MWh; } \\
\text { Closed sites } 0.2 \\
\text { ROCs/MWh; } \\
\text { landfill heat } \\
\text { recovery sites } 0.1 \\
\text { ROCs.MWh } \\
\end{array}$ \\
\hline & Gate Fees & $100-140 \$ /$ tonne & 100-140 \$/tonne & 100-140 \$/tonne & $60 \$ /$ tonne & $33 \$ /$ tonne \\
\hline & $\begin{array}{l}\text { Feed-In } \\
\text { tariffs }\end{array}$ & $\begin{array}{c}\text { for micro CHP - } \\
2 \mathrm{kWe} \text { or less } \\
0.17-0.19 \$ / \mathrm{kWh} \\
\end{array}$ & 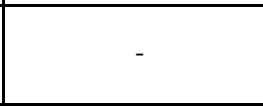 & 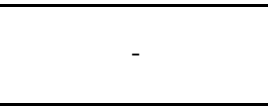 & $0.15-0.23 \$ / \mathrm{kWh}$ & 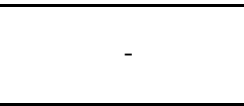 \\
\hline & $\begin{array}{c}\text { Renewabl } \\
\text { e Heat } \\
\text { Incentive }\end{array}$ & $0.04 \$ / \mathrm{kWh}$ & $0.04 \$ / \mathrm{kWh}$ & $0.1 \$ / \mathrm{kWh}$ & $\begin{array}{c}\text { for biogas combustion or } \\
\text { biomethane injection } \\
0.1 \$ / \mathrm{kWh}\end{array}$ & - \\
\hline \multicolumn{2}{|c|}{$\begin{array}{l}\text { Technology prominence/ } \\
\text { establishment }\end{array}$} & High prominence & $\begin{array}{l}\text { Not established } \\
\text { (RDF mainly } \\
\text { exported) }\end{array}$ & Emerging & Emerging & High prominence \\
\hline \multicolumn{7}{|l|}{ COST } \\
\hline \multicolumn{2}{|l|}{ Capital cost ${ }^{\mathrm{a}}$} & $620-700 \$ / \mathrm{tpa}$ & $620-700 \$ / \mathrm{tpa}$ & $620-850 \$ / \mathrm{tpa}$ & $310-460 \$ / \mathrm{tpa}$ & $\begin{array}{c}\text { At least } 50 \% \text { less } \\
\text { than capitalcosts of } \\
\text { AD }\end{array}$ \\
\hline \multicolumn{2}{|l|}{$O \& M \operatorname{cost}$} & $\begin{array}{l}10 \% \text { of capital } \\
\text { cost }\end{array}$ & $\begin{array}{l}\text { higher compared to } \\
\text { incineration due to } \\
\text { processing of RDF }\end{array}$ & $\begin{array}{c}10-12 \% \text { of capital } \\
\text { cost }\end{array}$ & $1-6 \%$ of capital cost & $\begin{array}{c}0.4-0.7 \% \text { of capital } \\
\text { cost }\end{array}$ \\
\hline \multicolumn{2}{|c|}{ Pre-treatment cost } & None & $\begin{array}{c}\text { Medium - } \\
\text { pelletisation }\end{array}$ & $\begin{array}{l}\text { High - segregation } \\
\text { and shredding }\end{array}$ & $\begin{array}{c}\text { Medium - segregation } \\
\text { required }\end{array}$ & None \\
\hline \multicolumn{7}{|c|}{ RISK } \\
\hline \multicolumn{2}{|c|}{$\begin{array}{l}\text { Impact of inadequate waste } \\
\text { segregation }\end{array}$} & Low & Low & High & Medium & Low \\
\hline \multirow{2}{*}{\multicolumn{2}{|c|}{ Air \& W ater Pollution }} & $0.22 \mathrm{~kg} \mathrm{CO}_{2} / \mathrm{kWh}$ & $\begin{array}{l}\text { Lower than } \\
\text { unprocessed MSW }\end{array}$ & $0.11 \mathrm{~kg} \mathrm{CO}_{2} / \mathrm{kWh}$ & $\begin{array}{c}\text { Net positive } \\
\text { environmental gains } \\
\text { achievable } \\
\end{array}$ & $1-1.2 \mathrm{~kg} \mathrm{CO}_{2} / \mathrm{kWh}$ \\
\hline & & $\begin{array}{c}\text { Small quantity } \\
\text { waste water to } \\
\text { dispose of }\end{array}$ & $\begin{array}{l}\text { Small quantity waste } \\
\text { water to dispose of }\end{array}$ & $\begin{array}{l}\text { Small quantity waste } \\
\text { water to dispose of }\end{array}$ & Medium water pollution & $\begin{array}{l}\text { Medium-High water } \\
\text { pollution }\end{array}$ \\
\hline \multicolumn{2}{|c|}{$\begin{array}{l}\text { Hygiene/ health \& safety } \\
\text { risks }\end{array}$} & $\begin{array}{l}\text { Small contribution } \\
\text { to local } \\
\text { concentrations of } \\
\text { air pollutants }\end{array}$ & $\begin{array}{l}\text { Small contribution to } \\
\text { local concentrations } \\
\text { of air pollutants; use } \\
\text { of RDF as feedstock } \\
\text { reduces risk of } \\
\text { vermin and pests }\end{array}$ & $\begin{array}{l}\text { Clean, minimal } \\
\text { health and safety } \\
\text { risks }\end{array}$ & $\begin{array}{l}\text { Potential microbial } \\
\text { infection hazards and } \\
\text { physical injury arising } \\
\text { from sharp contaminants } \\
\text { due to handling of MSW; } \\
\text { potential asphyxiation } \\
\text { and explosion hazard } \\
\text { from methane build up if } \\
\text { not well ventilated }\end{array}$ & $\begin{array}{c}\text { Potential } \\
\text { asphyxiation and } \\
\text { explosion hazard } \\
\text { from methane build } \\
\text { up if not well } \\
\text { ventilated }\end{array}$ \\
\hline \multicolumn{2}{|c|}{$\begin{array}{l}\text { Lack of resources/technical } \\
\text { expertise }\end{array}$} & Low & Medium & $\begin{array}{c}\text { High - lack of skilled } \\
\text { expertise }\end{array}$ & Low & Low \\
\hline \multicolumn{2}{|c|}{$\begin{array}{l}\text { Requirement of large land } \\
\text { area }\end{array}$} & 0.8 hectare & 0.8 hectare & 0.8 hectare & 2 hectares & 36 hectares \\
\hline
\end{tabular}

${ }^{\mathrm{a}}$ The 2015 exchange rate of 1 Pound Sterling (GBR) to 1.55 USDollars (USD) has been used 